\title{
Tackling burnout among senior clinicians: the paediatrician
}

\author{
Consultant paediatrician Anna Baverstock talks to Helen Jones about why she loves her specialty \\ and her work helping senior clinicians to model good wellbeing practices
}

\section{Helen Jones}

London, UK

Anna Baverstock's interest in wellbeing began 18 years ago. "I was pregnant with my daughter and I had a really bad run of on-call shifts," she says. "I looked after three babies and children who subsequently died.

"I sat with my educational supervisor, Fiona Finlay, and reflected on how hard paediatrics can be and how we're not very good at talking. I did some qualitative research as a registrar to see how other people coped with difficult shifts and it's grown from there."

She initially focused on looking after junior doctors-providing access to rest rooms and hot food at night and making sure there were enough staff to provide cover. She quickly realised that senior doctors needed support too.

"I persuaded my colleagues to give me some time to look at the wellbeing of senior doctors-it's quite a new role nationally and I'm very grateful to my trust," she says.

Baverstock looked at national and international evidence to see what was stopping senior doctors from delivering excellent patient care. "It's often the same thing that's getting in the way of us maintaining our own wellbeing," she says.

"Burnout is linked to many factors, so we're looking at workloads, job planning, and looking after ourselves as a group and how we take breaks-not just empowering our junior doctors to take breaks but also acting as role models as senior doctors."

Baverstock now spends just under half her time as associate director of medical education for junior doctor training, support, and wellbeing, exploring how junior doctors can be better supported and avoid burnout.

The rest of her time is spent in her clinical role-running clinics at the hospital and working in the community in special schools, as well as providing palliative care for children in their own homes. Baverstock specialises in looking after children with complex neuro-disabilities, social communication challenges, autism spectrum disorders, and attention deficit hyperactivity disorder.

"The lovely thing about my role as a community paediatrician is that it's holistic in nature and very family centred," she says. "The privilege of having been a consultant for 14 years is knowing families over a very long period of time and being able to see young people grow and transition into adult services." She says that, while the traditional view is that paediatricians "go around in knitted jumpers with comedy stethoscopes," paediatrics provides you "a real breadth" of medicine. "I'd encourage any medical student to give it a go and at least try a foundation job in paediatrics to experience the variety-from intensive care to community paediatrics," she says. "At a time when there are more and more specialties, there's something rather lovely about being a generalist," she adds.

As for her personal wellbeing, Baverstock says that her family keeps her grounded. "I have a fabulous husband and three teenage children who make sure I walk the wellbeing walk, as well as the talk, so I run with the dog, do yoga, and spend a lot of time in my kitchen with my family."

\section{Nominated by Claire Hope}

"Anna's skills and interests go far beyond her clinical work. In her paediatric work, she manages the needs of a hugely complex mix of patients with compassion and patience. She is empathetic and caring, and teaches these skills to all juniors who come through the department.

"Beyond this, Anna has a hugely positive impact on the wellbeing of the staff both in her own department and in the wider hospital. She supports trainees through the challenges they face and shares her knowledge and kindness to help trainees in all specialities to achieve their goals while maintaining their love of their work

"Personally, Anna has supported me through uncertain times in my career and has inspired me to strive for the passion she has in all of her roles to help her patients and colleagues thrive."

Claire Hope is a paediatric registrar at Musgrove Park Hospital

This interview was conducted in February. Since then much has changed. Anna would like to thank colleagues personally at Somerset NHS Foundation Trust for supporting each other and embracing the need for colleague wellbeing. But a special thank you must go to Phil Shelley for providing essential coffee, food, parking, and so much more during these challenging times.

Nominate a role model: to nominate someone who has been a role model during your medical career, send their name, job title, and the reason for your nomination to arimmer@bmj.com

Published by the BMJ Publishing Group Limited. For permission to use (where not already granted under a licence) please go to http://group.bmj.com/group/rights-licensing/ permissions 